\title{
Perspectives on lithospheric evolution through tectonomagmatic processes: a volume in honour of Jaroslav Dostal—an introduction
}

\author{
J. Gregory Shellnutt ${ }^{1}$. J. Brendan Murphy ${ }^{2}$ John D. Greenough ${ }^{3}$. J. Duncan Keppie ${ }^{4}$
}

Published online: 26 February 2018

(c) Springer-Verlag GmbH Germany, part of Springer Nature 2018

\section{Jaroslav Dostal: a pioneer in geochemistry}

Jaroslav Dostal, known as Jarda to friends and colleagues, is a scientific leader and a pioneer of lithogeochemistry and its application to tectonic processes (Fig. 1). Jarda's research career is now well into its fifth decade and his publication record is impressive both in terms of quantity (314 refereed papers and 8650 citations) and quality. He has published in a wide variety of prestigious journals, on the national and international scenes. For much of this time, his work has focused on mineralogy, geochemistry, mineral deposits, tectonics and petrology of igneous rocks. He has tackled every important petrological process from mantle evolution to magma mixing to liquid immiscibility in rocks ranging from Archean to recent in age. His contribution to any one of these fields of research is sufficient to have merited a firstclass international reputation. By any measure his contributions are outstanding.

\author{
J. Gregory Shellnutt \\ jgshelln@ntnu.edu.tw \\ J. Brendan Murphy \\ bmurphy@stfx.ca \\ John D. Greenough \\ john.greenough@ubc.ca \\ J. Duncan Keppie \\ johnduncankeppie@gmail.com
}

1 Department of Earth Sciences, National Taiwan Normal University, 88 Tingzhou Road Section, Taipei 11677, Taiwan, Republic of China

2 Department of Earth Sciences, St. Francis Xavier University, 5009 Chapel Square, Physical Sciences Centre, Room 2052, Antigonish, NS B2G 2W5, Canada

3 Department of Earth and Environmental Sciences, University of British Columbia, Okanagan, 3333 University Way, Kelowna, BC V1V 1V7, Canada

4 Departamento de Geologia Regional, Institute de Geologia, Universidad Nacional Autonoma de Mexico, Ciudad Universitaria, 04510 Mexico, D.F., Mexico
This volume is an outcome of a symposium entitled "Secular Variations in the Tectonomagmatic Evolution of the Continental Crust" held in Jarda's honour during the American Geophysical Union, Canadian Geophysical Union, Geological Association of Canada, and Mineralogical Association of Canada Joint Assembly in Montréal, Canada from May 3rd-7th, 2015. The symposium featured 16 contributions from friends, colleagues and former students. Many of the papers presented at the Joint Assembly have corresponding manuscripts in this volume, whereas others are contributions from friends and colleagues that wished to support this commemorative volume and their research collaboration with Jarda.

Jarda completed his undergraduate degree at Charles University in Prague in 1964 and Ph.D. at McMaster University in Hamilton in 1974. After completing his Ph.D. degree, on the geochemistry and petrology of the Loon Lake pluton in Ontario, he moved to Nova Scotia and became a professor at Saint Mary's University in 1975 where he established the Regional Geochemical Centre, served as Department Chair for 12 years and supervised dozens of undergraduate and graduate students. Much of his early work was focused on uranium and rare earth geochemistry of igneous and metamorphic rocks in regions such as Sardinia, Algeria, Iran, the Canadian Shield and the Andes. His studies on the distribution of uranium and related elements in volcanic rocks are an impressive contribution, spanning much of the geologic timescale and in all corners of the globe. These studies were many years ahead of the vast volume of literature that ultimately related these elements to a combination of primary and secondary processes. Not content with the geographic limitations of continents, he was involved in Deep Sea Drilling Projects. In the late 1970s his work around the Mediterranean expanded to include Greece, the western Alps and the Massif Central, and parts of North Africa.

By the early to mid-1980s, Jarda became a world authority in the various manifestations of igneous rocks, modern and ancient, and on a wide variety of petrological processes 


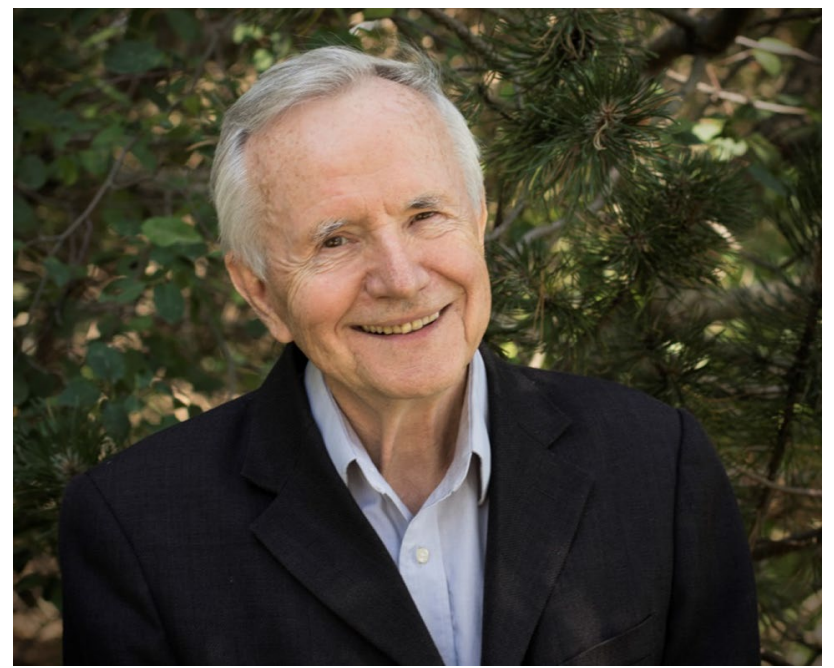

Fig. 1 Jaroslav Dostal in Halifax, Nova Scotia (July, 2017)

associated with their genesis. Jarda tackled important petrological problems by providing compositional constraints and textural insights to predict their tectonic environments. During this time, Jarda was one of the first to point out that continental tholeiites may not fit into traditional trace element discrimination diagrams because of the effects of crustal contamination, principles he used to great effect in his studies on the Precambrian, Paleozoic and Mesozoic continental tholeiitic rocks in Atlantic Canada. His work on the Coppermine and Natkusiak tholeiitic basalts in the western Arctic stimulated much discussion and further research on the petrogenesis and tectonic setting of these rocks. By the late 1980s, Atlantic Canada had begun to reap the dividend from Jarda's accumulated expertise. By that time, he had authored or co-authored papers on virtually every conceivable age and type of igneous activity in the Northern Appalachians, then, a pre-Mesozoic-type example for the relationship between igneous and plate tectonic processes. Jarda's thinking was well ahead of the pack and most of his basic conclusions are still as valid as the day they were written.

In the 1990s, he was involved with a number of landmark studies. For example, his 1992 paper (with Mueller) on Archean shoshonites in the Abitibi is important because it provides clues as to whether modern tectonic environments provide meaningful analogues for Archean settings. His 1996 paper on the inception and demise of a pre-Pan-African ocean basin in Algeria is a very important contribution to our understanding of Neoproterozoic global-scale orogenic activity. In 1996 and 1998 papers on the ocean island basalts from French Polynesia, he showed how the distribution of light elements such as boron, lithium and beryllium may be used as tracers for the character of subducted components. His papers on the early Mesozoic dykes of Atlantic Canada also stand out as a contribution to our understanding of the timing, setting and igneous manifestations of the early stage of Pangaea rifting. More recently, Jarda has focused much of his research on Precambrian complexes in Mexico, granites of the Central Asian Orogenic Belt in Mongolia, and the formation of the rare metal deposit at Bokan Mountain Complex in Alaska.

Jarda's contributions extend beyond research as he has served a number of professional institutions and volunteer agencies. He was a member of the Saint Mary's University Senate and served as a member of the Board of Governors; Chair of the Volcanology and Igneous Petrology Division of the Geological Association of Canada, Director of NAFTA (North American Free Trade Agreement) project North American mobility in higher education in Geology; Chair of Earth Sciences committee of Science Atlantic; Scientific Advisory Board of Geological Institute Academia of Science Czech Republic and spearheaded an international development project in Mongolia through the Canadian International Development Agency. Due to his contributions in research and administration Jarda has received recognition from his peers (Hawley Medal, Gesner Medal, Career Achievement Award, Volcanology and Igneous Petrology Division- GAC), students (Excellence in Teaching) and university (SMU President's Award in Excellence in Research).

And so $50+$ years after Jarda embarked on his research career the breadth and depth of his contributions spans some of the most fundamental concepts in the field of mineralogy, geochemistry, igneous petrology and their relationship to tectonics. Jarda has been an inspiration to colleagues and students as he tackled some of the most important petrological challenges of our time and consistently provided novel and plausible insights into fundamental processes responsible for them. This special issue is a testament to his career achievements and his enduring friendships with his colleagues and students.

\section{Foreword to the special issue}

This special issue of International Journal of Earth Sciences comprises papers submitted by friends and colleagues of Jaroslav Dostal to celebrate his contributions to the fields of geochemistry, geology and tectonics. The manuscripts are linked together by the common thread of understanding lithotectonic processes that control and govern the evolution of the upper most layer of the solid Earth. The authors do this using a variety of methods but primarily through geological observations and application of modern analytical techniques that can quantify and trace the geochemical processes that operate as a consequence of plate tectonics. The purpose of compiling these papers is to develop new ideas on how the lithosphere evolves over time. As such, they provide a fitting tribute to Jarda's outstanding career 
that is inspired by the pursuit of understanding the geotectonic evolution of the Earth. The topics in this volume cover a broad range of subjects related to lithospheric evolution including development of oceanic crust and ophiolites, the formation of large igneous provinces, granite petrogenesis, porphyry $\mathrm{Cu}$ deposits and new views on Gondwana, Avalonia, Appalachian Magmatism, Mexico and Central Europe.

Greenough and McDivitt review the geochemistry of basalts from ten continental flood basalt (CFB) provinces representing nine large igneous provinces. They discovered that basalts transecting Archean lithosphere are enriched in $\mathrm{Rb}, \mathrm{K}, \mathrm{Pb}$ and $\mathrm{Th}$ compared to those cutting younger lithosphere. They relate these differences to efficient transfer of alkali metals and $\mathrm{Pb}$ from subducted slabs in association with forming Archean tonalite-trondhjemite-granodiorite terranes. Archean lithosphere-cutting CFB is also "depleted" in $\mathrm{P}, \mathrm{Ti}, \mathrm{Nb}$ and $\mathrm{Ta}$ compared to the $\mathrm{CFB}$ cutting younger lithosphere suggesting stabilization of oxide phases in Archean slabs and retention of the latter three elements in these phases. The authors show that the characteristics of the Archean-cutting CFB resemble Enriched Mantle 1 (EM1) oceanic island basalts; EM1 may represent Archean subcontinental lithospheric mantle returned to the convecting oceanic mantle.

Polat et al. report major and trace elemental geochemistry and $\mathrm{Sr}-\mathrm{Nd}-\mathrm{Pb}-\mathrm{O}$ isotopic data from the anorthosite, leucogabbro, gabbro units and mafic dykes of the Neoarchean Doré lake complex (DLC) of the Superior Province, Canada. The major and trace elemental geochemistry indicate that DLC consists of two distinct magma series: (1) the anorthosite-leucogabbro series and (2) the gabbro-mafic dyke series. The $\mathrm{Sr}-\mathrm{Nd}-\mathrm{Pb}-\mathrm{O}$ isotopes suggest that the rocks were likely derived from a depleted mantle source but their trace element compositions are similar to modern arc magmas, specifically a suprasubduction environment. The authors suggest that the DLC and neighbouring volcanic and intrusive rocks of the Obatogamau Formation are fragments of oceanic crust that formed within a back-arc basin.

Solari et al. present new $\mathrm{U}-\mathrm{Pb}$ and $\mathrm{Hf}$ isotopes from the Sonoran Proterozoic basement in NW Mexico. These data suggest the presence of several types of crystalline components: (1) the Bámori Complex yielded 1.7-1.78 Ma U-Pb ages with $T_{\mathrm{DM}}$ ages of 2.1-2.4 Ga, (2) orthogneisses gave $1.64-1.7 \mathrm{Ga} \mathrm{U}-\mathrm{Pb}$ ages and $T_{\mathrm{DM}}$ ages of $1.65 \mathrm{Ga}$; (3) the Pinal Schist with $1.67-1.69 \mathrm{Ga} \mathrm{U}-\mathrm{Pb}$ ages and $T_{\mathrm{DM}}$ ages of $1.9 \mathrm{Ma}$; and (4) post-tectonic granites dated at $1.44 \mathrm{Ga} \mathrm{U}-\mathrm{Pb}$ ages and $T_{\mathrm{DM}}$ ages of $1.8-1.9 \mathrm{Ga}$ and $1.6-1.7 \mathrm{Ga}$. These data suggest either the presence of the Caborca-Mojave and Mazatzal provinces with an intervening Proterozoic suture or that the orthogneisses represent the source of the posttectonic granite.

Pe-Piper and Piper combine detailed field observations, mineralogy, petrography and geochemistry to document the style of emplacement and the role of volatiles in the emplacement of a Late Neoproterozoic appinite complex (Jeffers Brook complex). These authors show how appinites are small volumes of arc-related magmas that trap aqueous fluids and intrude the upper crust by exploiting active faults.

Linnemann et al. provide evidence for a new Ediacaran glaciation in the Bohemian and Iberian massifs, both of which are parts of Cadomia that lay along the Gondwanan margin. U-Pb-Hf isotopic data constrain the glaciomarine deposits between 562 and $565 \mathrm{Ma}$ of detrital zircon and granitoid clasts in the diamictite and 538-540 Ma ages of cross-cutting plutons. As these events post-date the 579-581 Ma Gaskiers glaciation, they propose the term Weesenstein-Orellana glaciation for the new Ediacaran glacial event.

Hoffman et al. present a geochronology study of detrital zircons from the Saxonian-Bohemian Cretaceous Basin. Most of the Elbtal Group sedimentary material is thought to have a northern provenance. The main age clusters are similar to the Bohemian Massif (local material) but there is a dearth of Upper Proterozoic to Lower Palaeozoic ages indicating the Lausitz Block was probably covered at the time of deposition. The sandstones of the Elbe valley (Elbtal Group, Schmilka section) represent the re-deposited sedimentary cover of the Lausitz Block in inverse order and comprised Permian, Triassic, Jurassic and Lower Cretaceous deposit. Within some samples of the Elbtal Group (Schmilka section), there is a major input of Meso- and Paleoproterozoic zircons. The authors further investigate the origin of Triassic to Jurassic sedimentary rocks from Bavaria and Lower Saxony and offer a possible tectono-sedimentary interpretation of the region during the Mesozoic.

The Rumburk granite in the Lausitz block of the SaxoThuringian zone of the Bohemian massif is the focus of geochronological and geochemical study by Zieger et al. The Rumburk granite yielded a zircon $\mathrm{U}-\mathrm{Pb}$ intrusive age of $504 \pm 3 \mathrm{Ma}$ with inheritance ages of ca. 540 and $610 \mathrm{Ma}$, which together with geochemical data suggest a source in the Lusatian arc-derived greywackes. The Rumburk granite is inferred to be part of the initial phase of rift-related Rheic magmatism on the northern margin of Gondwana.

The tectonic affinity of the Meguma terrane within the context of the Appalachian orogen is a long-standing controversy. Some syntheses advocating that the Meguma was contiguous with the neighbouring Avalon terrane throughout the Paleozoic and others maintaining they accreted to Laurussia as separate terranes. Identifying the age and isotopic characteristics of the basements to these terranes is crucial to resolving this controversy. Keppie et al. present a detailed geochronological and isotopic analysis of the ca. $440 \mathrm{Ma}$ Brenton pluton that yields ca. 550 and $700 \mathrm{Ma}$ inherited ages and $\mathrm{Hf}$ isotopic analyses of zircon that are typical of Avalonia. By incorporating paleomagnetic and faunal data, 
they further suggest that the Meguma/Avalon was an island chain near Baltica during the Neoproterozoic.

Braid et al. focus on the generation and emplacement of plutonic rocks and mafic dykes from the South Portuguese Zone of the Iberian Peninsula. The authors report new major and trace elemental geochemistry and whole rock $\mathrm{Nd}$ isotopes of a suite of Early Carboniferous mafic and felsic rocks. The results indicate that the mafic rocks formed within an arc environment and that the magmas were derived from a metasomatized enriched mantle wedge source. The granitic rocks, on the other hand, are thought to be derived from a mixed mafic and crustal source that melting during post-collision slab break-off. The implication is that the Variscan collision between Laurussia and Gondwana was protracted and complex.

López-Moro et al. provide $\mathrm{U}-\mathrm{Pb}$ ages for a peraluminous granitoid in the Torres Dome, part of the Central Iberian Zone in the Variscan Orogen. These ages include a crystallization age of ca. $320 \mathrm{Ma}$, and inherited ages of ca. $345 \mathrm{Ma}$, ca. 390-432 Ma, ca. 450-511 Ma 540-840 Ma, and $900-2700 \mathrm{Ma}$. The ca. $320 \mathrm{Ma}$ age is interpreted as the timing of decompression crustal melting driven by the extensional collapse of the orogenic belt in this domain of the Variscan chain of Western Europe. Furthermore, it suggests that a crustal layer of ca. 340 Ma granitoids/migmatites was recycled, partially or totally, only $15-20 \mathrm{My}$ after its emplacement.

Grajales-Nishimura et al. report new U-Pb geochronology results and in situ zircon $\mathrm{Hf}$ isotopes and zircon trace elemental data from a suite of mafic and felsic rock collected from the Juchatengo complex (JC) of southern Mexico. The lithologies of the JC suggest that it is likely representative of the upper layers of an ophiolite sequence. The new $\mathrm{U} / \mathrm{Pb}$ geochronology results on the plagiogranites indicate that the JC rocks were emplaced during the late Carboniferous to early Permian. A slightly younger (280 to $275 \mathrm{Ma}$ ) tonalite intrudes the complex and younger sediments. The zircon $\mathrm{Hf}$ isotopes of the JC rocks suggest they were derived from a primitive mantle source, whereas the younger tonalite was likely contaminated by continental crust. The authors suggest that the JC ophiolite was generated in a back-arc setting during oblique collision of the paleo-Pacific plate below the amalgamated Oaxacan and Acatlán complexes.

Shellnutt et al. present new whole rock and trace elemental geochemistry of Early Jurassic basalt from the Fundy Group of Nova Scotia. Mantle potential temperature $\left(T_{\mathrm{P}}\right)$ estimates of the North Mountain basalt indicate they were likely produced under a thermal regime $\left(T_{\mathrm{P}} \approx 1450{ }^{\circ} \mathrm{C}\right)$ that is close to ambient mantle $\left(T_{\mathrm{P}} \approx 1400{ }^{\circ} \mathrm{C}\right)$ conditions and are indistinguishable from other regions of the Eastern North American sub-province of the Central Atlantic Magmatic Province. The consistent $T_{\mathrm{P}}$ along the $3000 \mathrm{~km}$ long ENA suggests that the CAMP was unlikely to be generated by a mantle plume. Moreover, mantle potential temperature estimates appear to distinguish the mantle source compositions of the Northern Appalachians from the Southern Appalachians. The authors suggest the spatial-compositional variation of the ENA basaltic rocks is related to differing amounts of melting of mantle sources that reflect the uniqueness of their regional accreted terranes (Carolinia and West Avalonia) and their post-accretion, pre-rift structural histories.

Sepahi et al. report on the mineralogy, geochemistry and age of pegmatites and aplites in the Alvand intrusive complex, of the Hamedan region (Zagros orogen) in Iran. The peraluminous, Li-, Cs- and Ta-bearing, Muscovite Rare Earth Element-class pegmatites yielded Jurassic (172-154 Ma) U-Pb ages that overlap those for plutonic rocks of the Alvand complex. The authors propose advective heating in a continental arc setting caused melting of fertile meta-pelitic supracrustal rocks. The resulting felsic magmas then underwent extensive fractionation. The study supports the role of syn-subduction partial melting of the crust in yielding these geochemically anomalous pegmatites and aplites.

Zentilli et al. examine the petrochemical characteristics of the ore-bearing Eocene-Oligocene silicic porphyry intrusions and the supposed 'ore-barren' Triassic granodiorites of the Chuquicamata District of the northern Chile. The Triassic granodiorites and the Eocene-Oligocene rocks are almost identical in composition and responded similar to hydrothermal alteration thus making them difficult to discern in the field. The super-giant porphyry $\mathrm{Cu}$ deposits of Northern Chile were largely formed during a 10 million interval (41-31 Ma) that represents only $5 \%$ of the total 200 million year period of magmatism. The authors suggest that the late Triassic volcano-plutonic centres situated in the same setting as the ore-bearing rocks may have contained ore deposits but that their preservation and economic significance depends on the extent of erosion. Moreover, both of the late Triassic and Eocene-Oligocene magmatism were terminal stages of an active volcano-plutonic cycle, and preceded major shifts in the volcanic front and the character of magmas generated, which in turn reflected major changes in plate interaction.

Sarjoughian et al. present new whole rock geochemical data from a suite of rocks collected from the Zafarghan igneous complex (ZIC) of central Iran. The ZIC is a bimodal intrusive complex that consists of granite, granodiorite, diorite and gabbro and was emplaced during the late Oligocene $(\sim 25 \mathrm{Ma})$. The rocks have a calc-alkaline composition and trace element characteristics similar to arc rocks. The authors suggest that the granitic rocks are produced by mixing between magmas derived from juvenile lower crust and older continental crust. Moreover, the resultant magma fractionated to produce the highly silicic rocks of the ZIC. It is suggested that the ZIC was formed at an active continental margin setting within the Central Iran microcontinent. 
Mai et al. discuss the tectonomagmatic evolution of the South China Sea. They outline the distribution of the temporal and geographical reconstruction of Cretaceous and Cenozoic magmatism with the isochrones of major basins around South China Sea. The reconstructions indicate SE margin of Asia has experienced at least two crustal thinning events related to the subduction rollback of the Pacific plate followed by subduction of the Neotethys oceanic lithosphere. The rifting sites are controlled by localized thermal weakening by magmatism. The interaction of two continental stretching events followed by localized magmatic thermal weakening is the likely cause of the non-volcanic nature of SCS.

Two papers Pereira et al. (107/1: 251-267) and Murphy et al. (107/2: 587-599) intended for this special issue were mistakenly published in issues 1 and 2 respectively.

Voluminous Carboniferous magmatism is one of the defining characteristics of the Variscan orogen. However, the triggers and sources of his magmatism are controversial. Pereira et al. present U-Pb data from S-type granites of the Mêda-Escalhão-Penedono Massif (Central Iberian Zone) that constrain the timing of emplacement to ca. $318 \mathrm{Ma}$, an age that is coeval with late D2 extensional shear in which metamorphism resulted in anatexis. U-Pb data of inherited zircon cores are similar to ages documented in Ediacaran to Silurian host rocks of the Iberian autochthonous and parautochthonous domains, suggesting a genetic relationship between S-type granite generation and the host metamorphic rocks, and little or no role for new material from mantle sources.

A-type granites are typically thought to be either the result of anhydrous partial melting of lower crustal residue after extraction of felsic magma, or derived by fractionation either of alkaline mafic magmas or of hybrid mafic and felsic magmas. Murphy et al. propose that additional insights into the genesis of these magmas can be gained by focusing on terranes where such magmatism occurred in repeated episodes over a long period of time. Using the Avalon on northern mainland Nova Scotia as an example, they propose that when the crustal source becomes dehydrated, a terrane will repeatedly produce A-type magmas irrespective of the tectonic environment.

Acknowledgements We are thankful to all of the authors and reviewers for their contributions that have made this volume dedicated to Jaroslav Dostal a successful endeavor. We greatly appreciate the willingness of International Journal of Earth Sciences to publish this volume, and the support from Wolf-Christian Dullo (Editor-in-Chief) and Monika Dullo (Editorial Manager) for making the special issue a fulfilling and enjoyable experience. 